DOI: $10.1515 /$ ausp-2015-0021

\title{
Transylvanianism as Identity Discourse
}

\author{
Imola Katalin NAGY \\ Department of Applied Linguistics \\ Sapientia University Cluj-Napoca \\ Faculty of Technical and Human Sciences Târgu-Mureş \\ nimolkat@gmail.com
}

\begin{abstract}
This paper aims at making a presentation of the main regional ideologies of the Transylvanian cultural and spiritual life in the interwar period. The Hungarians' Transylvanianism and the Romanians' creative localism or ardelenism alike offered a wide range of key concepts and ideas that shaped/and were shaped by the cultural context of the time. Both regionalisms - Romanian and Hungarian - shared many of these concepts and ideas, although they never really sustained an open and efficient communication due to a series of causes. The shifts that occurred in the self-defining strategies, the communication breakdowns that characterized the relationships between the two cultural milieus and intellectual circles, the identity discourses that can be spotted in the media of that time, and the movement known as Transylvanianism are all approached with the purpose of identifying the causes that hindered real and efficient communication between Romanians and Hungarians.
\end{abstract}

Keywords: Transylvanianism, regional ideology, identity discourse, intercultural communication

In 2000, three Hungarian scholars, György Csepeli, Antal Örkény, and Mária Székely published a very intriguing study on the way Central Europeans perceive themselves and, above all, one another. Grappling with national identity. How nations see each other in Central Europe, issued by the Publishing House of the Hungarian Academy of Sciences, deals with an aspect that represents one of the central concerns of this present study, i.e. the representations Romanians and Hungarians have had on each other over the past decades. The conclusion drawn by Csepeli and his fellow researchers is that one of the stereotypes of ethnic relations in Transylvania at the beginning of the third millenium is moral disdain: "In Transylvania, Hungarians and particularly Romanians not only perceive cohabitant people as different, but they also morally disdain them." (Csepeli et al. 2000: 100) 
In Transylvania, this prevalence of ethnocentrism syndrome focusing on collective suffering and self-pity, and the tendency towards self-victimization on part of Romanians and Hungarians alike (as the above mentioned study identifies), is not an unknown or a surprising phenomenon. There is an important and complex network of causes that can explain such attitudes, and these causes are connected with the social, political, and cultural history of a province that has been sheltering these neighbouring nations and cultures for centuries. We shall not try to offer an indepth analysis of this network of reasons, yet we attempt to approach one of the most important factors that have shaped the communication between Romanians and Hungarians from Transylvania, namely the regional ideology called Transylvanianism, following its evolution in the first part of the $20^{\text {th }}$ century.

The debates upon the issue of intercultural communication in interwar Transylvania and the various aspects of national identity and alterity must take into consideration the so-called Transylvanian ideology. During the first four decades of the $20^{\text {th }}$ century, several regional ideologies were operating on the European continent, and the Central and Eastern parts of it were no exception (Neubauer and Cornis Pope 2006: 5). Transylvanianism appeared and spread in Transylvania, while Europe became more and more receptive to the regional ideas promoted by Josef Nadler and August Sauer, while Leo Frobenius's Paideuma was published in Münich in 1921. In the 1920s, Sauer's and Nadler's Landschaftstheorie became more and more popular; the latter's book, Literaturgeschichte der Deutschen Stamme und Landschaften, had a huge impact on the development of other regional theories, among which Al. Dima's creative localism. Similar regional ideas and thoughts were promoted by the German movement called Heimatdichtung or the French régionalisme.

Transylvanianism is the Transylvanian regional ideology, which gained huge popularity, on the one hand, and triggered a lot of critical remarks, on the other hand. Its main feature was the activism it promoted. Numerous Hungarian intellectuals from Transylvania embraced Transylvanianism, but the regional ideas were widespread among the Romanian and the Saxon cultural milieus as well. Traditionally, Transylvanianism is considered and defined as an interwar regional ideology developed and promoted by the Hungarian writers of the time. Zsolt K. Lengyel refers to two periods in the history of Transylvanianism - early Transylvanianism and the Helikon period (K. Lengyel 2007: 24). The three main principles of this ideology were: multiculturality (as it sprang from the three neighbouring cultures of Transylvania), love for the native land, and the need of establishing and following aesthetic criteria in literature.

There are moments and events that foreshadowed the rise of the Transylvanian ideology as early as the Transylvanian School/ Şcoala Ardeleană movement with the Romanians or the dualism in the history of the Hungarians (K. Lengyel 2007: 42). As Mircea Zaciu puts it, "it has been unanimously acknowledged 
that beginning with the Transylvanian School, this Romanian province (i.e. Transylvania) has brought an explosive energy to the nation's movement of ideas and has also enriched certain literary chapters like poetry or the novel. It has emphasized epic, social, ethnic and ethic aspects, all major categories necessary to a young literature often lured by mirages from far off that may take the form of the integration into European rhythms. Between tradition and modernity, a battle that has been fought at various times by different protagonists and yet is essentially the same, Transylvania has been assigned the fief of Tradition by long-term prejudice. It wanted to test the Transylvanian aesthetic conservatism and resistance to the new, in its finest forms. Paradoxically, the values of this province remain actual and sometimes very modern, while others, ostentatiously modern, did not pass the test of time ... But the meanings Transylvania assumes in our national consciousness transcend the strictly aesthetic spheres." (Zaciu 1994: 19-20)

After 1900, the term Transylvanianism started to be used more and more often in the Transylvanian media. The very first time Transylvanianism ${ }^{1}$ was used as an argument in a debate was in 1902, in the controversy of Endre Dózsa, the sub-prefect of Cluj County, with a Budapest newspaper, Pesti Napló. În 1905, Hungarian poet Endre Ady presented the image of Transylvania as a land of freedom and a haven of cultural and spiritual safety in his poem Egy ismeretlen Korvin kódex margójára. In 1908, Endre Dózsa uses the term Transylvanianism in Transsylvanismus. Elnöki megnyitó in the Cluj newspaper Erdélyi lapok. In 1912, Károly Kós’s review Kalotaszeg. Képes hetilap (7 Jan.-26 March 1912 - Stana) appeared, and this is considered another pre-transylvanist moment. The objective of the editor was to publish and promote his theory on Transylvanianism (K. Lengyel 2007: 41, Pomogáts 1983: 82).

There are several definitions of the Transylvanianist ideology. The majority of the writers from the Erdélyi Helikon group gave a definition; among these, one can cite the names of Lajos Áprily, Mária Berde, Károly Kós, Károly Molter, Aladár Kuncz, Géza Tabéry and others. All these writers believed that Transylvania had a specific spirituality that had been shaped along the centuries, rooting from the Transylvanian geography (landscape) and history, and was based on a very strong connection with the land and its people. Its basic features were tolerance and well-balanced attitudes towards otherness, differentness. Károly Kós was the main spokesperson of the Transylvanianist ideology, and he considered this region unique due to its variety and intercultural crossings. He even wrote a book called Transylvania, a sketch of cultural history, in which he argued for the existence of a specific Transylvanian spirituality, shaped by the landscape, the history and the cultural diversity of the region. As Gábor Flóra puts it, Kós wanted to define a specific Transylvanian identity, hinting at the very particular

1 The term has been used under the forms transsylvanismus, transzilvanizmus, transzilvánizmus, or more recently transzszilvanizmus. 
geography of the region, which induced a specific economic and social status, arguing that all these distinctive geographical features, corroborated with the region's history, led to a very special Transylvanian culture, to which the coexisting nations added some of their own spiritual particularities though keeping their own peculiar spirituality unaltered (Flóra 1999: 201).

There is a long list of Romanian writings dedicated to the topic of Transylvania; among the most important names, one should mention those of D. Popovici (1943), I. Breazu (1944), G. Ibrăileanu, E. Lovinescu, G. Călinescu, I. Chinezu etc.

Quite importantly, the issue of literary and cultural regionalism appears in the pages of the literary magazine Gând românesc, the idea being that historical circumstances, on the one hand, and the intention to bring the province in line with the country, on the other, represent the data of the aforementioned paradigm. The efforts of Ion Breazu, Vasile Bancila and, naturally, Ion Chinezu to assert Transylvania's place within the national culture, to dissociate the terms of a unique physiognomy found expression in magazine articles, lectures and, of course, studies (Chinezu, 1997: 15).

Liviu Rebreanu, the famous Romanian novelist, writes in 1929 a preface to a volume dedicated to Hungarian prose writers from Transylvania, Povestitori unguri ardeleni, in which he tries to define the profile of the Transylvanian writer and Transylvanian writing. Rebreanu emphasizes the strong connection with the land and the people, and that the act of writing is an act of apostolic sacrifice: "The art of these authors is never a mere play on words or intentions. The Transylvanian writer, perhaps more than ones from elsewhere, feels himself eternally tied to the land and considers his art a form of apostolate. This is why literature mirrors more strongly the soul of the people, with its yearnings, joys and hopes." (Lupu 1928: 4)

Bucur Tincu refers to the prototype of the Transylvanian intellectual, whose main features are: traditionalism, a strong connection with the social background, activism and dynamism (Todor 1983: 306). The painter Catul Bogdan considers the seriousness and depth of the Transylvanian soul and spirit the outcome of the western milieu in which the Transylvanians lived (Todor 1983: 307).

Transylvanianism is approached in terms of alterity and difference in Vasile Băncilă's article (published in Gând românesc, 1939, no. 7-9: 170) entitled Semnificația Ardealului/The Significance of Transylvania, which is an insight into the spiritual history and geography of Transylvania: "we know that others talk about Transylvania and document its significance for them. There is also a term Transylvanianism that has been circulating for a while. Sometimes, it has political connotations, promoting a so-called mutual Transylvanian soul, common for all the people living here, disregarding and neglecting the ethnic realities. But this is denied by history, by the psychology of the nations and by the philosophy of culture. Moreover, they empasized, on several pathetic 
occasions, how sacred Transylvania is for them. But let us make things clear: it is only a second-hand sacredness. A sanctity of the ego and of self-suggestion." (Băncilă 1939, no. 7-9: 170) The article does not deal with the Transylvanian regional ideology in terms of principles or arguments, the author denies it by erasing the writers who promote it. He uses plenty of impersonal phrases, such as others, they, avoiding to accuse anybody directly, but being obviously hostile to the whole phenomenon. The conclusion of the article is that not only did intercultural communication fail, but it did not even come into being. Băncilă ends his article by introducing a special kind of I statement, the we element, in strong opposition with they: "who has spoken about our tragedy for the past two millenia? They, the Hungarians, swaggered ... They took our goods, our wealths, our freedom, our churches, our right to pray, our ballads/doinas... even our kings.” (Băncilă: Semnificația Ardealului in Gând românesc, 1939, no. 7-9: 172)

In a completely different register, E. Bucuța publishes an article in a magazine called Boabe de grîu in September 1932, in which he refers to the necessity of intercultural communication and the causes for which Romanians and Hungarians fail to establish contacts. The myth of the first comer also appears in the article, which promotes the idea that the two nations should start forgetting about their past injuries and present fears, and start a necessary and unavoidable process of intercultural exchanges (E. Bucuța under Boabe de grîu, 1932, no. 9: 439-440).

After studying the Romanian cultural press from Transylvania (Gând românesc, Provincia literară, Cele Trei Crişuri, Țara noastră, Boabe de grâu, Pagini literare, Familia, Societatea de mîine, Revista Fundațiilor Regale, Blajul, Abecedar), we have come to the conclusion that Transylvanianism is criticized in a large number of articles, but it is approached with openness and constructive criticism in others, while some writings prove to be even more understanding. There is a clear distinction between the Hungarians' Transylvanianist ideology, called transzszilvanizmus, and the Romanians' regional ideology usually referred to as ardelenism or localism creator. The idea of a transnational Transylvanian spirit is not accepted in the Romanian press of the time, but the idea that spirituality can be determined by the geographical features - an idea common to all regional ideologies - is accepted. It is not the Transylvanian idea that is rejected by the Romanians, but its Hungarian connotations; the very distinctive term they use to refer to their own regionalism (transilvanism vs. ardelenism) is meant to avoid any confusion or mix-up with the Hungarians' regional approach.

The contribution of the Romanian essay writers must be mentioned as well as the essay literature proved to be more open to the Transylvanian ideology and recognized its positive outcomes in a more efficient way. We have in mind, in this sense, the writings of Ion Chinezu, Avram P. Todor, Nicolae Balotă, Mircea Zaciu and others. In fact, it was Zaciu's book, Ca o imensă scenă, Transilvania ..., published in 1996, which did not avoid the term transilvanism and first used it along with ardelenism 
to refer to the regional impulse of the Romanians. The book is an attempt to define a so-called Transylvanian spirit, and the author launches the idea that there is a special Transylvanian soul, and - just as the Hungarians did in the interwar period - he defines Transylvania not only as a geographical or historical space but also as a cultural concept. "As a matter of fact, historical consciousness seems to me to be the characteristic component of the Transylvanian spirit. More than once, in connection with it, it has been also mentioned its ethnicism and militantism, a tendency toward Benedictine reasoning, whence the subordination of the aesthetic to history, ethics, culture, etc. Do these come from the cultural education, do they come from the rural strata where all Transylvanian writers originate, remaining afterwards peasantscholars for all their lives? One should not ignore their permanent connection with the West either, their refusal of the Balkan spirit, which they considered inferior and harmful for art, the refusal of the city as a form of oppression (since the city was considered alien) but the identification with the entire Romanian space, the adhesion to a higher form of urbanization, the dream of a library-fortress, a place of scholarly education and achievement." (Zaciu 1994: 25)

Mircea Zaciu also identifies the very peculiar set of attitudes that have always characterized Transylvanian writers, i.e. preference for action, defensiveness and dedication for the national cause: "However, it has been said that Transylvania did not have the necessary time to indulge in the true enjoyment of art. Its spirit, permanently required by the need of defense, permanently assailed by the dangers of estrangement through more subtle forms or through brutal denationalization was too much trained for action ..., public thinking ..., historical philosophy ..., conceived as a tool used in proving its historical existence. ... Even theology was taken down from the sacerdotal pulpit to be employed in lay objectives, like political education, the acquiring of rights, emancipation. The first image of Transylvania is, therefore, a wistful, cultural one, in agreement with the corpus of ideas pertaining to the enlightment." (Zaciu 1994: 23)

The definition proposed by Gavril Scridon resembles Károly Kós’s concept of Transylvania, as the Romanian critic describes the special Transylvanian spirit loci, characterized by the profound love of the land, a tremenduous attachment to history and openness towards the others (Scridon 1996: 18).

Ion Chinezu writes in his Aspects of Transylvanian Hungarian Literature that "Transylvanianism surfaced when Transylvania turned its face towards Bucharest. This is the truth. We shall not dwell on the political meaning of this statement, on the deeper roots of Transylvanianism, on the spectre of the buffer-state sometimes discernable behind this word. Restricting the discussion to the realm of literature, we shall try to see if there is an art-generating Transylvanianism, a specific soul of the region, a Transylvanian way of thinking, capable of crystallizing itself into its own form of literature. Such an approach of the issue is within the field of literary geography. Well, it is beyond doubt that a Transylvanianism of this kind does 
exist, and that it also existed when it was being ignored, the same way one could discern a Moldavian, Muntenian, Transylvanian and Oltenian soul in Romanian literature. There is no Transylvanian writer of certain standing who did not mention Transylvanianism, which is viewed by some as the axis of the literature in this area... a deep sense of nature, an interesting mixture of conservatism and modernism, a sense of leveling eclecticism and a marked ethical character (to which L. Rebreanu refers too): this is the framework in which we should put this literature in order to understand it in its true light." (Chinezu 1997: 47-48)

Transylvanianism attracted another Romanian critic as well, namely Nicolae Balotă, who defines it as an ideology that came into being due to the work of Károly Kós, who invented Transylvanianism as a semiotic system, holding the signs and symbols of Transylvanian lifestyle. He rejects the criticism that blamed Kós for having created a simple romantic vision, with one eye on the past and one eye on the landscape (Balotă 1981: 29).

If we try to resume the main ideas that shaped the Transylvanian ideology, we must mention that it had two main pillars, relying on two main arguments, namely the geography and the history of Transylvania that gave birth to a special Transylvanian spirituality. The positive aspects of this spirituality and the main elements of Transylvanianism as an identity discourse are: tolerance, multiculturality, multilingualism, readiness to take action, defensive tendencies, an urge to protect national identity, respect for the mother tongue, anti-central attitudes and a strong need for freedom, europenism etc.

In 1932, a very similar ideology appeared in Sibiu when Al. Dima and other intellectuals (Paul I. Papadopolo, Tiberiu Iliescu, Pimen Constantinescu, George Fonea, Ion. Th. Ilea, Ionel Neamtzu and Horia Petra-Petrescu) founded the Thesis Group/ Gruparea Intelectuală Thesis along with an art review, Provincia literară, later continued by Sibiul literar. After the Great Union of 1918, an interesting phenomenon occurred, i.e. a phenomenon of poligenesis (Fanache 1973: 2), which means a strong and rapid revival of the Transylvanian cultural centres. This led to the appearance of a remarkable number of newspapers and magazines (Braşovul literar/Braşov 1931, Provincia literară/Sibiu, 1932, Lanuri/ Mediaş, 1933, Gând românesc/ Cluj, 1933, Abecedar/ Brad, 1933, Progres şi cultură/Tg.Mureş, 1933, Pagini literare/Turda, 1934, Sibiul literar/Sibiu, 1934).

It is interesting to note that the members of the Thesis Group had a special taste for debate, which makes their resemblence to the Hungarians' Helikon movement even more interesting. What is more, Dima called his group a creativity workshop (un atelier de confruntare în problemele creației, Fanache 1983: 66), while the Erdélyi Helikon group was defined a literary plein-air parliament. "Localism does not mean isolation or exaggerated use of some realities limited to a given area. On the contrary, it proclaims an aspiration toward integration and affirmation through distinct, unique voices in the concert of a national culture." (Chinezu 1997: 15) 
The ideology of the group was crystellized, among other writings, in Dima's article, Localismul creator/ Creative localism (Familia, 1935, no. 2, reproduced in Blajul, 1935, no. 3, and in Revista Fundațiilor Regale, 1935, no. 7 and 9). The key terms Dima makes use of are time/space, tradition/contemporaneity. Dima hesitates in the usage of the terms localism and/or regionalism, and finally decides upon the first one to avoid the confusion with the regional approach of the Hungarians, i.e Transylvanianism, though Dima's localism wishes to promote local creativity and recommends local topics for literature. In the same time, localism, just like Transylvanianism, is meant to promote local values, the beauty of the landscape and the uniqueness of its specific spirituality (Dima, Localismul creator, in Blajul, 1935, no. 4: 174). The professor from Sibiu is aware that his approach has parallels in the Hungarians' and Saxons' cultural activities, and he knows that their Transylvanianism has very similar objectives to his own creative localism, namely to help and facilitate the creation of high-quality aesthetic productions (Dima, Localismul creator, in Blajul, 1935, no. 4: 175). The same ideas appear in Andrei Ungheri's article Literatura săsească ardeleană din zilele noastre/ The Contemporary Saxon Literature in Transylvania (Blajul, 1935, no. 5). Dima expresses the same awareness in other articles as well; what is more, he constructs his theory on the same bipolar system of arguments as the Hungarians. His creative localism relies on "geographical and social arguments; within each region there are lands with their own specific physiognomy... their geography leads to a relatively autonomous spiritual life ... which proves that our localist programme can definitely lead to solid and genuine works of art .... the previous argument is completed with historical arguments as well ... Creative localism has always been dominant in the Romanian cultural life; in point of quality and quantity, local literary movements have always been better than central ones .... " (Ungheri, Literatura săsească ardeleană din zilele noastre in Revista Fundațiilor Regale, 1935, no. 9: 718)

The members of the Thesis group lived in Sibiu and they kept close contacts with their Saxon fellow writers. Their relationship with the Hungarian intellectuals of the time is not known. That is why, the numerous similarities between the two movements - Dima's localism and the Hungarians's Transylvanianism are so striking. In this respect, we can identify the following common features: both ideologies are based on the geographical and historical arguments, both intend to design a special spiritual geography of Transylvania, they both assume their identity as going against centralist tendencies, and they are both identity discourses. The Helikon group and the Thesis group alike try to impose aesthetic criteria in the evaluation of literary productions, and they both implement and organize a wide cultural movement (editing papers, publishing books, organizing conferences etc.). We do not wish to develop the issue of the aesthetic value of the books the writers belonging to the two groups wrote as this is sometimes debatable. Yet, we must mention, that some of the best Hungarian writers of 
the interwar period belonged to the Helikon group and openly assumed their Transylvanianist convictions. What differentiates the two groups is that the members of the Thesis group rejected, at least on a declarative level, their implication in political activities.

Nevertheless, the two movements did not establish or facilitate intercultural communication. There are several causes of this failure, among which we mention the national traumas of the Romanians before and those of the Hungarians after 1918. Another cause is the rise of nationalism and its career in both countries, as, in different periods, both Romanian and Hungarian authorities displayed nationalistic attitudes in their official policies. Another cause could be the overuse of the term Transylvanian (in the names of papers, magazines, groups, titles of books etc.), which might have provoked rejection on the part of the Romanians, who preferred to state their belonging to the newly formed state by the the use of the adjective Romanian (e.g. Gând românesc) and not Transylvanian. Another cause is the political involvement of regionalism, in such a way that even literary and aestehtic productions were rejected and criticized by and because of political criteria. An interesting example of the interference of politics into cultural matters is an article signed by Romulus Dianu and first published in Curentul (17 June 1933), and then reproduced in Primul Buletin al Grupării Intelectuale Thesis din Sibiu. Dianu makes highly appreciative remarks on the activity of the members of the Thesis group, but defines their localism as a movement that must go against similar tendencies in the other Transylvanian cultures: "the state policies will make use of them (the Thesis writers) ... when their work will become a form of counterattack against the cultural block of the ethnic minorities." (Primul Buletin al Grupării Intelectuale Thesis din Sibiu, 1932-1933: 37)

In order to build up a healthy and functional image, each community must construct communication channels and surfaces where the history, the values and the traumas of the community can be deposited. In this respect, the printed media has one of the most important roles. This applies to the interwar Transylvanian society as well. One of the main topics of the Romanian newspapers was the so-called crisis of the Transylvanian press, which stated that the golden age of the Romanian press from Transylvania was not under Romanian government but under the opression of the Austro-Hungarian authorities. On the other hand, the Hungarian press seemed to flourish in the 1920s and 1930s, and a lot of Romanian journalists instanced it as an example to follow for the worsening Romanian publications (Onisifor Ghibu's article, O soluție în chestia presei din Ardeal/ A Solution in the Problem of the Transylvanian Press, published on 30 January 1926, in Societatea de mâine, no. 5: 71)”. N. Ghiulea expresses the same idea on $17^{\text {th }}$ January 1926, in an article entitled Pentru presa Ardealului/For the Press of Transylvania, where he blames the Romanian press for losing its traditional roles: maintaining nationalism alive, educating citizens and creating leaders 
(Societatea de mâine, 1926, no. 3: 33). In the first issue of the same month, I. Lupaş publishes Criza presei ardelene/The Crisis of the Transylvanian Press, where he debates upon the same topic, in the same way.

There is a very simple explanation of this seemingly strange phenomenon: the main roles of the pre-war Romanian media from Transylvania (shaping and reinforcing national identity, propaganda, activating hidden energies, striving to resist oppression, nourishing survival instincts, etc) were simply overtaken by the Hungarian media, which had become better, along with a loss of quality of the Romanian papers. The huge change that occured in 1918 led to a role shift in the Transylvanian society, and this logic of reversed roles might stand as an explanation for the decay of the Romanian press and the flourishing of the Hungarian one. The status of the two nations dramatically changed; thus, a transfer of behaviours, attitudes and cultural phenomena took place.

Another cause of the lack of efficient and open communication between the Romanians and Hungarians might be the impossibility of forgetting, which is, according to Cornis Pope and Neubauer, specific for Central Europe: "The Central Europeans are ignorant of the science of forgetting, of filing away events... and this is both their strength... but also their weakness that makes them prone to repeated conflict. The memory of their great national traumas has often prevented the peoples in the region to forget or reinvent history, seeking new possibilities of interaction. But this obsessive memory has also allowed them to retrieve those periods, however short-lived, when multicultural interaction seemed like a real possibility, as in the second half of the $18^{\text {th }}$ century and the beginning of the $19^{\text {th }}$." (Neubauer and Cornis Pope 2004: 222)

Another stereotype related to Transylvanianism is that the Hungarians' regionalism was mainly political and the Romanian one mainly cultural. It is more accurate if we say that there are several packages of discourse about Transylvanianism. Some of these were against Transylvanianism, some others displayed ambiguous attitudes, hesitating between rejection and acceptance, while others were favourable and even obsessive, exclusivist Transylvanianists as well. We can refer to a soft and a hard version of Transylvanianist or anti-Transylvanianist attitudes. The hard variant allows nationalism and narrow thinking to spread and flourish, whereas soft Transylvanianism implies Europeanism, intercultural communication, critical thinking and acceptance of differences.

Transylvanianism has been considered beneficial and progressist only when it refers to my regionalism, my Transylvanianism: when it comes to the others' Transylvanianism, the regional ideology becomes subject to powerful negation and vehement disputes. "The closer the chosen enemy is, the more convincing and thus real the constructed danger becomes, and the lack of a group's own identity... projects itself onto the unknown but threatening other ... in EastCentral Europe, the identification or evaluation of us automatically also isolates 
and evaluates as positive everything that we claim to be ours, an act which is impossible to perform without simultaneously fencing in the space of ourselves." (Neubauer and Cornis Pope 2004: 378)

There is a number of principles that were laid down in the 1920s that foreshadow the $21^{\text {st }}$ century European ideas. In point of different types of Transylvanianism, some say that there is a Romanian and a Hungarian Transylvanianism, while some others say there is a transnational variant as well. Applying another set of criteria, we can mention early Transylvanianism, flourishing Transylvanianism (the 1920s), a Transylvanianism in crisis (the 1930s), and a neo-Transylvanianism (the 2000s). There is a cultural Transylvanianism and a political one too, but the interference of the political discourse was natural between the two world wars. There is a restrictive form of Transylvanianism, which leads to provincial literature, but there is another type of Transylvanianism with strong European accents, which promoted modernity. While the first form nourished nationalistic fobias and false patriotism, the progressive Transylvanianism was promoted by Chinezu, Balotă, Kuncz or Kós, and gave names like Rebreanu, Slavici, Tamási or Ady.

All the aspects of the interwar Transylvania have that in-betweenness, mentioned by Cornis Pope and Neubauer; it is natural that Transylvanianism is also in-between cultural and political, national and European, traditional and modern. Transylvanianism is based upon the idea that space can determine and shape the spirit, that certain geographical features of a landscape may imprint a certain forma mentis. This idea is accepted and promoted by both Transylvanianisms, Romanian and Hungarian alike, becoming evident even in the articles published in the interwar period. Transylvanianism was alternatively assumed by the two nations, and even if Hungarian intellectuals are traditionally referred to as the creators of the Transylvanianian ideology, one cannot state that it has been exclusively a Hungarian brand. A large segment of its ideas and arguments could be found in writings belonging to Romanian men of letters of the time, though they claimed they did not belong to the Transylvanianist movement, and they called their attitudes ardelenism or creative localism. The causes of this denominative separation lie within the characteristics of Central European self-defining strategies (Neubauer and Cornis Pope 2004: 378). Such negative or oppositional self-definitions did not allow that the very same term designate the Hungarian and the Romanian regional tendencies alike. The two types of Transylvanianisms operated with the same set of keywords and phrases, with the same ideas and arguments (as we have already mentioned, Transylvanianian geography, history, Transylvanianian spirit, Transylvanianian idea, anti-centralism, a wise balance between tradition and modernity, taste and openness to European ideas, etc). One of the most striking failures of Hungarians' Transylvanianism and the reason for which Romanians argued against it was that it could not acknowledge that roles had shifted and it tended to require 
the same patience and unconditioned openness they had refused to provide some years earlier. Delicate topics have become taboos over the past decades and the nations from Transylvania have failed to reach a stable compromise due to psychological causes that made Romanians incapable to understand the extent to which Hungarians were traumatized by the Treaty of Trianon, and which made Hungarians incapable of perceiving the signals Romanians had sent them before 1918, and how dramatic the 1940 loss of Northern Transylvania was for them.

Transylvania is the birthplace of the nation for both ethnic groups. "Therefore, no wonder that while the modern Romanian nation is being built, its literature appeals to Transylvania in an attempt to engage its forces under the same banner of unity. Transylvania is no longer just the birthplace of the Romanians. It is also the birthplace of culture... Therefore, Transylvania acquires the meaning of birthplace of Romanians." (Zaciu 1994: 20-21) Both Hungarians and Romanians from Transylvania define themselves by their Transylvanian roots and neither admits or accepts the others' right to do so. History and the past are equally used to give arguments and motivate actions of the present, and rememorizing a glorious and mythical historical background can always establish and reinforce the dividing line between we and the others. Representing the image of the inimical other is similar all over Central Europe; thus, the set of ingredients of representing otherness is almost the same with the Romanians and Hungarians alike, and they include nationalism and attitudes towards this such as history and mother tongue. The formation of national identities has very specific mechanisms in areas called multicultural corridors by Neubauer and Cornis Pope. "The new us emerges not so much through positive self-recognition but rather through the negation of not-us-entities, singled out and labeled as the annihilating energy which constantly endangers our invented us ... practically this also means that the survival of one group, regardless of its ethnic, racial or social background, directly depends on the demise of another group or groups." (Neubauer and Cornis Pope 2004: 378) The article signed by Ion Băilă, Caracteristica culturii minoritare/The Characteristics of the Minority Cultures, deals with the topic of the contacts between Transylvanian cultures, and its main idea is linked to the building of hostile images of the others. "The circumstances have made it that the Romanian public opinion perceive the ethnic minorities only as unpleasant, political elements. The same thing happened with the minorites as well, and they judge us according to the way they are treated by the authorities. The cultural aspects have been completely neglected on both sides." (Băilă, Caracteristica culturii minoritare in Societatea de mâine, 1926, no. 20: 378)

Margit Feischmidt develops the same idea when she refers to the so-called disputed territorries marked by a double loyalty of its citizens, those geographical areas that belong politically to one state, but at the same time the linguistic and ethnic loyalties of a large part of the population are directed towards another 
state. This is the very situation that can easily lead to deep and difficult conflicts. The paradox of the nationalistic attitudes in such areas and, at the same time, the tragedy of the small nations of Eastern Europe is that - although the geography of such territorries is made up of several microregions - the national ideologies that arise here do not take into consideration this aspect and are rather centred on territorry and not on multiculturality (Feischmidt 2005: 20).

The motives of we/ the others, my nation/ the other nation are strongly linked with the issues of national identity and multicultural territories. Valér Veres refers to two main types of national identity: the Western European type, based on the concepts of country and citizenship, and the Eastern European type, based on the concepts of ethnic origin and culture (Veres 2005: 88). In the Central and Eastern parts of the European continent, in the region of the former big multinational empires, the nations have constructed their national identities on cultural, linguistic and ethnic attributes; that is precisely the reason for which ethnic rivalry and inherent conflicts are most likely to occur right where ethnic plurality has remote historical roots and traditions (Grúber 2002: 13). John Neubauer and Marcel Cornis Pope define the cultural milieu from Transylvania with the help of a conflictual paradigm, mixed with rivalry and mutual neglect, which cannot erase those multicultural crossings that are still operating (Neubauer and Cornis Pope 2004: 5). In Transylvania, similarly to other parts of Central Europe, regionalism functioned as an alternative to the centralist approaches. The Hungarians' Transylvanianism and the Romanians' Transylvanianism or creative localism were nothing else than such regional movements.

Defensive anxieties are always a symptom of poor intercultural communication. We can apply György Csepeli's ideas on the prevalence of ethnocentrism syndrome in Transylvania to the interwar period as defensive attitudes and ethnocentric anxieties were widespread phenomena in those times as well: "In Transylvania, both Romanians and Hungarians tend toward self-victimization, which is a paradoxical version of ethnocentrism focusing on collective suffering and self-pity." (Csepeli et alii 2000: 149) Such anxieties prevented the interwar Transylvanian intellectuals, Romanians and Hungarians alike, from establishing open and efficient communication, and that is why Transylvanianism did not fulfil the role it might have fulfilled, and it separated people instead of reuniting them. Besides the above mentioned causes, the articles on the problem of Transylvania provide some more causes for this communication fiasco: some literary topics that proved to be too delicate to bear (for instance, a lot of Hungarian writings were criticized by the Romanians not because of their poor aesthetic value but because they dealt with the delicate topic of history), nationalism, stereotypical attitudes such as superiority vs. inferiority complex, europenism vs. balcanism, the question of who came first, whose home is Transylvania, who has more rights to rule it, etc. 
Mythology and history are very important factors in identity building all over Central Europe, and so are they in Transylvania. The conflicts are likely to appear where myths and historical figures or events are interpreted one way by one group, but rather differently by the other. When history appears reinterpreted or even negated by the inimical other, when it is not infallible anymore and when alternative variants show up, conflicts arise (Schöflin 2003: 98). A particular case of conflict-generating situations is when myths penetrate the historical discourse and mythical figures are perceived by the collective unconscious as absolute truths; thus, any criticism of the myth is interpreted as an attack that endangers the integrity of the whole nation (as in the above mentioned article by Vasile Băncilă, Semnificația Ardealului). Mitteleuropa is characterized by this tendency to create historical and histerical public discourses, and the relationship between the Romanians and Hungarians are intertwined by such mythical elements and arguments (Schöflin 2003: 100).

One of the most interesting cases of promoting nationalism as a valid and necessary argument for both parts is a text signed by Corneliu Codarcea, Sigismund Móricz în Ardeal/Móricz Zsigmond in Transylvania, in which the publicist concludes that nationalism or intolerance have always been the normal ingredients of Transylvanian militantist discourses (Codarcea, Sigismund Móricz în Ardeal in Țara noastră, $12^{\text {th }}$ December 1926, no. 50: 1479).

The representations of differentness in interwar Tranylvania are ambivalent, and they are based on dichotomies like similarity/difference, identity/alterity, we/ the others, both with the Romanians and the Hungarians alike. Two neighbouring nations, occupying and coexisting on the same territory, have created parallel and rival identity discourses. In the press of the time, there are numerous articles that exemplify such discourses. Both the Romanians and the Hungarians consolidated the ethnocentric side of their national awareness. One of the stereotypes of interethnic relations in Transylvania, besides differentness, is moral disdain. In a large number of articles, there is an extremely stigmatized representation of the other, but in other writings the need to become more open towards each other is urged. Nevertheless, in the collective unconscious of both nations, there is a stereotypical ethnic hierarchy, which always places the other onto an inferior position and status. This phenomenon might be explained by the evolution and career of nationalism in Europe in general and in Central Europe in particular, although we do not intend to develop this topic hereby. We cite, in this sense, an article signed by Cronicar, where the author signals the regional ideas that are promoted in the Hungarian literary and cultural review Erdélyi Helikon (Societatea de mâine, 1928, no. 16-17: 285). Cronicar (most probably Teodor Murăşanu) makes a short historical overview of the ideology, and refers to the centralist economic and cultural tendencies of Budapest at the end of the $19^{\text {th }}$ century. Due to some peculiarities, the peripheries of the Monarchy resisted these tendences: "in regions 
like Transylvania, Banat, Croatia, etc., an intense cultural and economic activity of the populations that were the majority developed and, in comparison with this activity, the one of the Hungarians was inferior despite all the advantages provided by the state, and perhaps due to this very centralist behaviour of Budapest" (Cronicar under Societatea de mâine, 1928, no. 16-17: 285). Transylvanianism is, according to the author of the article, a kind of cultural regionalism that opposes "the retrograde and chauvinistic behaviour of Budapest, which is always in the clouds about reestablishing the situation prior to the war. And we are convinced that this new attitude (the Transylvanian ideology) will help the Hungarians from Transylvania ... ascend spiritually, through the creation of some important scientific and cultural values, by remaining loyal to the Romanian state, which will not hinder their activity, provided that it does not turn into a disguised conspiracy against its bases." (Cronicar under Societatea de mâine, 1928, no. 16-17: 285)

One of the dilemmas of the Transylvanian self-defining strategies is that, between the two world wars, this always takes place on the account of the other. Both cultures, the Romanian and the Hungarian alike, consider Transylvania an identity landmark, the birthplace of the nation, and this is the most probable cause of the long series of misunderstandings. In the interwar media, the definition of the self and of the other is always done by making use of the ethnic categories, and things have not changed tremenduously in the 2000s. Alterity and identity are talked about, referred to, used as arguments and stated as examples both by Romanians and Hungarians. Transylvanians tend to define themselves and the others from a national perspective, underlining the separating lines between the two parties (Fox 2005: 109). The discourse on us and the others is, at the same time, a discourse about the past, present and future, about nations and nationalities, about nationalism and European attitudes, about intercultural communication and its failures. Transylvania has always been, for every nation living here, an axis mundi, that is why the Romanian and the Hungarian identity discourses are equally impregnated by defensive reflexes and suspicions. Perhaps, these could reveal the roots and the motives of most nationalistic stereotypes that still operate these days. 


\section{References}

Balotă, Nicolae. 1981. Scriitori maghiari din România. 1920-1980. Bucureşti: Editura Kriterion.

Chinezu, Ion. 1997. Aspects of Hungarian Literature (1919-1929). Centrul de Studii Transilvane, Cluj, Fundația Culturală Română.

Csepeli, György-Örkény, Antal-Székely, Mária. 2000. Grappling with national identity. How nations see each other in Central Europe. Budapest: Akadémiai Kiadó.

Fanache, Maria. 1983. Un moment literar sibian interbelic - Thesis. In: Cercetări de limbă şi literatură II: 63-72.

Fanache, Vasile. 1973. Gând românesc şi epoca sa literară. Bucureşti: Editura Enciclopedică Română.

Feischmidt, Margit (ed.). 2005. Erdély-(de)konstrukciók. Tanulmányok. BudapestPécs: Néprajzi Múzeum-PTE Kommunikáció és Médiatudományi Tanszék.

Flóra, Gábor. 1999. Primii teoreticieni ai transilvanismului. In: Altera 10: 201.

Fox, Jon E. 2005. Vándorló nemzet(i) - identitások. Erdélyi vendégmunkások Magyaroszágon. In: Feischmidt, Margit (ed.), Erdély-(de)konstrukciók. Tanulmányok. Budapest-Pécs: Néprajzi Múzeum-PTE Kommunikáció és Médiatudományi Tanszék.

Grúber, Károly. 2002. Európai identitások: régió, nemzet, integráció. Budapest: Osiris-BIP.

K. Lengyel, Zsolt. 2007. A kompromisszum keresése. Miercurea-Ciuc: Editura Pro-Print.

Lupu, Ioan. 1928. Povestitori unguri ardeleni, antologie. Fundația culturală Regele Mihai I.

Neubauer, John-Cornis-Pope, Marcel (eds.). (2004/2006). History of the Literary Cultures of East-Central Europe. Junctures and Disjunctures in the $19^{\text {th }}$ and $20^{\text {th }}$ centuries. I-III. Amsterdam/Philadelphia: John Benjamins Publishing Company.

Pomogáts, Béla. 1983. A transzilvánizmus. Budapest: Akadémiai Kiadó.

Schöflin, György. 2003. A modern nemzet. Máriabesenyő-Gödöllő: Attraktor Kiadó.

Scridon, Gavril. 1996. Istoria literaturii maghiare din România. 1918-1989. Cluj: Editura Promedia Plus.

Todor, Avram P. 1983. Confluențe literare româno-maghiare: Eseuri. Bucureşti: Editura Kriterion.

Veres, Valér. 2005. Identitate etnică vs. identitate națională în poziție minoritară. In: Altera XI(26-27): 88.

Zaciu, Mircea. 1996. Ca o imensă scenă. Transilvania... Cluj-Napoca: Editura Fundației Culturale Române. 
Zaciu, Mircea. 1994. Transylvania’s Significance in Romanian Literature. In: Transylvanian Review III(3) (Autumn): 19-27.

\section{Series of magazines and newspapers:}

Abecedar. Indice bibliografic întocmit de Dona Daisa, Biblioteca Academiei RSR, filiala Cluj, serviciul de documentare şi bibliografie, Cluj, 1972.

Primul Buletin al Grupării Intelectuale Thesis din Sibiu, 1932-1933, Tip. Cav. Sibiu.

Gând românesc (1933-1939), Provincia literară (1934), Cele Trei Crişuri (19201921, 1937), Țara noastră (1933-1938), Boabe de grâu (1930-1934), Pagini literare (1934-1939), Familia (1926-1934), Societatea de mîine (1924-1940). 